\title{
Implementsi Program Imtaq Sebagai Upaya Penguatan Nilai-Nilai Keagamaan Anak Di SDN 1 Lembah Sari
}

\author{
Riadi \\ Program Studi Pendidikan Guru Madrasah Ibtidaiyah Fakultas Agama Islam \\ Universitas Muhammadiyah Mataram \\ Jl. K.H. Ahmad Dahlan No. 1 Pagesangan - Mataram \\ Korespondensi Penulis: laluasriadi15@gmail.com, musfet14@gmail.com
}

\begin{abstract}
ABSTRAK
Kata Kunci : Implementsi Imtaq, Penguatan Nilai-Nilai Keagamaan

Dalam rangka meningkatkan keimanan dan ketaqwaan anak didik kepada Allah SWT, setiap sekolah memiliki program yang mendukung terwujudnya pribadi-pribadi yang islami, program yang bisanya dilaksanakan pada jumat pagi sebelum pelajaran dimulai. Program inilah yang disebut dengan program imtaq yakni program yang dihajatkan untuk meningkatkan keimanan dan ketaqwaan anak didik. Program ini memiliki posisi strategis dalam membantu menguatkan materi-materi yang diajarkan di kelas terutama pada mata pelajaran agama Islam. Setidaknya ada tiga hal yang ikut melatar belakangi pentingnya program IMTAQ yaitu perta, dalam era globalisasi terdapat pengaruh negatif media elektronik dan media cetak terhadap kehidupan masyarakat; ke dua, kehidupan yang belum kondusif bagi upaya peningkatan iman dan taqwa; ke tiga, terjadinya prilaku menyimpang (tawuran pelajar, penyalah gunaan narkoba, penyimpangan seksual dan kenakalan remaja lainnya). Upaya ini tidak hanya tanggung jawab guru PAI saja, melainkan menjadi tanggung jawab bersama seluruh komponen pendidik disekolah, termasuk stake holder pendidikanAdapun penelitian ini menggunakan pendekatan kualitatif dilaksanakan di SDN 1 Lembah Sari Kecamatan Batu Layar Lombok Barat. Adapun hasil penelitian ini sebagai berikut Realisai kegiatan IMTAQ di SDN 1 lembah Sari dengan dua kegiatan yakni dengan kegiatan jumat rutin dan kegiatan diniyah sore, pelaksanaannya lima hari setiap pekan, adapun materi-materi yang diajarkan adalah materi yang bersentuhan dengan kebutuhan dalam hal praktek keagamaan sehari-hari. Materi yang mendasar bagi siswa adalah rukun iman, rukun Islam dan doa-doa keseharian. Materi tersebut diberikan secara teoritis dan praktis, hal tersebut dimaksudkan agar apa yang telah dipelajari oleh siswa langsung dapat dipraktikkan oleh siswa dalam kehidupan sehari-hari. Secara umum ada dua kendala yang dihadapi dalam implementasi IMTAQ yakni kendala teknis dan kendala substantif lebih pada kurang siapnya guru dan siswa dalam menyampaikan pidato (kultum) setiap kegiatan IMTAQ berlangsung.
\end{abstract}

\section{A. LATAR BELAKANG}

Dalam rangka meningkatkan keimanan dan ketaqwaan anak didik kepada Allah SWT, setiap sekolah memiliki program yang mendukung terwujudnya pribadi-pribadi yang islami, program yang bisanya dilaksanakan pada jumat pagi sebelum pelajaran dimulai. Program inilah yang disebut dengan program imtaq yakni program yang dihajatkan untuk meningkatkan keimanan dan ketaqwaan anak didik. Program ini memiliki posisi strategis dalam membantu menguatkan materi-materi yang diajarkan di kelas terutama pada mata pelajaran agama Islam.

Setidaknya ada tiga hal yang ikut melatar belakangi pentingnya program IMTAQ yaitu perta, dalam era globalisasi terdapat pengaruh negatif media elektronik dan media cetak terhadap kehidupan masyarakat; ke dua, kehidupan yang belum kondusif bagi upaya peningkatan iman dan taqwa; ke tiga, terjadinya prilaku menyimpang (tawuran pelajar, penyalah gunaan narkoba, penyimpangan seksual dan kenakalan remaja lainnya). Upaya ini tidak hanya tanggung jawab guru PAI saja, melainkan menjadi tanggung jawab bersama seluruh komponen pendidik disekolah, termasuk stake holder pendidikan. Karenanya pembelajaran pendidikan agama Islam idealnya diarahkan sebagai upaya internalisasi nilai-nilai spiritualitas (nilai agama) bukan hanya transper knowledge.

Salah satu PP nomor 55 tahun 2007 tentang pendidikan agama dan pendidikan keagamaan, pasal 1 disebutkan: pendidikan agma adalah 
pendidikan yang memberikan pengetahuan dan membentuk sikap, kepribadian dan keterampilan peserta didik dalam mengamalkan ajaran agamanya yang dilaksanakan sekurang-kurangnya melalui mata pelajaran pada semua jalur, jenjang dan jenis pendidikan. ${ }^{1}$ Namun secara khusus pendidikan agama dapat diartikan sebagai pendidikan yang terencana dalam menyiapkan peserta didik untuk mengenal, memahami, menghayati hingga mengimani ajaran agama Islam serta diikuti tuntunan untuk menghormati penganut keyakinan yang lain dalam hubungannya dengan kerukunan antar umat beragama hingga terwujud kesatuan dan persatuan bangsa. ${ }^{2}$

Walaupun demikian halnya pendidikan agama Islam (PAI) masih menuai keritikan ditengah-tengah masyarakat yaitu bahwa kurikulum PAI dipandang kurang berhasil dalam membentuk sikap dan prilaku peserta didik. Sebagai indikatornya antara lain adalah rendahnya minat dan kemampuan anak didik untuk melaksanakan ibadah, membaca al-Qur'an, berperilaku kurang terpuji, perkelahian pelajar, dan lain sebagainya. ${ }^{3}$ Oleh karena itu proses pembelajaran hendaknya diarahkan tidak hanya pada pemahaman materi melainkan pada terciptanya transpormasi dan edukasi sosial secara menyeluruh. ${ }^{4}$

Oleh karena itu, seiring terjadinya perubahan paradigma mengajar yang lebih menekankan pada 'peroses' daripada 'hasil', menekankan transpormasi atau internalisasi semata dibandingkan hanya tranfer pengetahuan semata. ${ }^{5}$ Maka untuk meminimalisir berbagai dugaan atau argumen miring terkai dengan pembelajaran Pendidikan Agama Islam (PAI) yang menekankan pada dimensi doktrin legal formal, peneliti tertarik untuk mengkaji tentang program IMTAQ sebagai upaya penguatan nilai-nilai keagamaan dengan judul "Implementasi Program IMTAQ Sebagai Upaya Penguatan Nilai-Nilai Keagamaan Anak di SDN 1 Lembah Sari".

\section{FOKUS KAJIAN dan TUJUAN SERTA MANFAAT}

Penelitian ini difokuskan pada beberapa hal yaitu pertama, bagaimana implementasi program IMTAQ di SDN 1 Lembah Sari; ke dua apa saja

\footnotetext{
${ }^{1}$ Lengkapnya, baca PP RI no. 55 tentang Pendidikan Agama Dan Pendidikan Keagamaan.

${ }^{2}$ Muhammad Alim, Pendidikan Agam Islam, Upaya Pembentukan Pemikiran dan kepribadian Muslim (bandung: Rosdakarya, 2006). Hlm 6

${ }^{3}$ Muhaimin, Arah Baru Pengembangan Pendidikan Islam (Bandung: Nuansa Cendekiawan, 2003).hlm. 183

${ }^{4}$ Tolhan dan Barizi, Membuka Jendela Pendidikan, mengurai akar Tradisi dan Integrasi Keilmuan Pendidikan Islam, (Jakarta: Grafindo Persada, 2004). Hlm. 41.

5 Hamruni, Strategi dan Model-Model Pembelajaran Aktif Menyenangkan (Yogjakarta: UIN Suka Press, 2009). Hlm. 38.
}

materi IMTAQ yang ditanamkan pada siswa dalam rangka Penguatan nilai-nilai keagamaan di SDN 1 Lembah Sari; dan ke tiga, apa saja kendala-kendala yang dihadapi dalam program IMTAQ di SDN 1 Lembah Sari.

Adapun tujuan penelitian ini adalah pertama, untuk mengetahui bagaimana implementasi program IMTAQ di SDN 1 Lembah Sari; ke dua mengetahui apa saja materi-materi IMTAQ yang ditanamkan pada siswa dalam rangka Penguatan nilai-nilai keagamaan di SDN 1 Lembah Sari; dan ke tiga, mengetahui cara mengatasi kendalakendala yang dihadapi dalam program IMTAQ di SDN 1 Lembah Sari. Tujuan tersebut dapat memberikan fanfaat baik dari segi teoritis yang dapat menambah khazanah keilmuan tentang penguatan nilai-nilai keagamaan, dan secara praktis dapat memberikan informasi dan menjadi acuan tata cara pelaksanaan program IMTAQ.

\section{RUANG LINGKUP DAN SETING PENELITIAN}

Pembatasan ruang lingkup penelitian ini bertujuan untuk membatasi penelitian yang akan dibahas agar lebih fokus. Adapun subyek penelitian ini adalah guru dan siswa yang melaksanakan program IMTAQ, dan obyek penelitian ini adalah pelaksanaan program IMTAQ di SDN 1 Lembah Sari serta setting penelitian dilaksanakan di SDN 1 Lembah Sari Kecamatan Batu Layar Lombok Barat.

\section{TELAAH PUSTAKA}

Untuk mencegah terjadinya plagiasi serta mendukung keabsahan data dalam penelitian ini. Ada beberapa penelitian yang terkait degan penelitian ini sebagai bahan perbandingan sebagai berikut:

1. Penelitian oleh Zulkarnaen, Fakultas Tarbiyah IAIN Mataram 2005, dengan judul " Pendidikan Agama Islam dan Pelaksanaannya pada kelas unggul di SMAN 1 Dompu". Penelitian ini hanya mendeskripsikan bagaimana pelaksanaan pendidikan agama Islam (PAI) yang diterapkan di sekolah unggul. Dalam konteks penelitian ini bahwa skiripsi tersebut masih berbicara tentang nilai partikuler pendidikan agama Islam yang tidak menyentuk pada ranah yang universal. Dan menjelaskan upaya-upaya yang dilakukan dalam menghadapi problema pembelajaran PAI.

2. Penelitian oleh Bediawati, Fakultas Tarbiyah IAIN Mataram 2009, dengan judul " Strategi Pendidikan Agama Islam dalam membina akhlaq di SMP 1 Praya Timur Lombok Tengah. Dengan tujuan penelitian adalah untuk mengetahui strategi guru PAI dalam membina akhlaq siswa. 
Berdasarkan hasil penelitian terdahulu yang telah dilakukan oleh peneliti tersebut di atas, maka penulis akan mengkaji penelitian dengan judul "Implementasi Program IMTAQ Sebagai Upaya Penguatan Nilai-Nilai Keagamaan Anak di SDN 1 Lembah Sari". Dengan terfokus pada bagaimana pelaksanaan pembelajaran PAI dan sekaligus pada bagaimana upaya penguatan penanaman nilai-nilai keagamaan. Dengan demikian jelaslah perbedaan penelitian ini dengan dua penelitian terdahulu yaitu terletak pada Implementasi Program IMTAQ Sebagai Upaya Penguatan Nilai-Nilai Keagamaan Anak.

\section{B. KERANGKA TEORITIK}

Fokus kajian ini adalah program imtaq dan nilai-nilai keagamaan anak. Oleh karena itu, kerangka teoritik yang perlu dipaparkan adalah yang terkait dengan program imtaq dan nilai-nilai keagamaan anak. Akan tetapi sebelum menjelaskan kedua hal tersebut, untuk mempermudah penulis, maka perlu juga menjelaskan pengertian implementasi dan penguatan. Implementasi dalam arti dasar yakni pelaksanaan, sedangkan pelaksanaan dapat diartikan proses dan cara melaksanakan. ${ }^{6}$ Dalam hal ini proses dan cara yang dimaksud tentu mengarah pada pelaksanaan program IMTAQ. Sedangkan penguatan menunjukkan pada upaya tambahan yang dilakukan diluar kegiatan rutin sebagai upaya memberikan pemahaman terhadap anak didik.

\section{Pembelajaran PAI Dan Program Imtaq}

Pembelajaran adalah istilah baru untuk menyebut 'pengajaran'. Perbedaan tersebut sebenarnya terletak pada prosesnya saja yaitu dalam pembelajaran guru sebagai fasilitator sedangkan pada pengajaran, guru memiliki peran lebih besar pada sumber tranfer ilmu kepada peserta didik. Setidaknya ada tiga makna yang dapat kita temukan yaitu satu; pembelajaran sebagai proses mengatur, memberikan stimulus kepada peserta didik, ke dua; yaitu siswa sebagai pusat kegiatan belajar, dan ketiga yaitu guru sebagai fasilitator, serta yang ke empat yaitu siswa sebagai subyek belajar. ${ }^{7}$

Terkait dengan pendefinisian PAI yaitu menunjukkan mata pelajaran di madrasah atau di sekolah umum. PAI yang dimaksud di sekolah adalah mata pelajaran PAI yang merupakan kumpulan materi keislaman. ${ }^{8}$ Adapun program imtaq yaitu masalah iman biasanya membahas

\footnotetext{
${ }^{6}$ Tim Reality, Kamus Terbaru Bahasa Indonesia (Surabaya: Reality Publisher, 2008). Hlm. 402

Hamruni, Strategi dan Model-Model Pembelajaran Aktif Menyenangkan, hlm. 38
}

rukun iman yang enam sedangkan materi taqwa lebih pada implementasi dari materi-materi keagamaan termasuk materi iman dan islam dalam bentuk perbuatan sehari-hari.

\section{Nilai-Nilai Keagamaan}

Pendidikan PAI sebagai sebuah mata pelajaran yang tidak terlepas dari pesan-pesan yang hendak disampaikan kepada para siswa yakni berupa nilai-nilai pada level sekolah dasar baik itu nilai etika atau estetika yang memiliki dua sudut baik itu partikular maupun universal. Dengan demikian tujuan dari pelajaran PAI adalah bukan sekedar pemahaman akan tetapi lebih pada menjalani hidup di atas nilai-nilai dasar agama Islam dalam arti akhlaqul kariimah dalam kehidupan sehari-hari. ${ }^{9}$

Berangkat dari dasar utama pendidikan Islam, maka setiap aspek pendidikan Islam mengandung beberapa unsur pokok yang terkait dengan nilai-nilai keagamaan, yaitu:

1. Nilai tauhid yaitu lebih mengarah kepada fitrah tauhid yang diajarkan melaui pembelajaran yang tidak bertentangan dengan ajaran Islam.

2. Nilai Ibadah yaitu pengabdian dalam praktek ibadah sesuai alqur'an dan hadist, yang menyentuh dua aspek yaitu hablum minalloh dan hablu minannas.

3. Akhlaq yaitu yang terkait dengan moral, normanorma dan kepribadian manusia sebagai makluk paling mulia diantara makhluk lainnya.

4. Dan nilai kemasyarakatan yakni pergaulan sesama masyarakat, berbangsa dan bernegara dan lain sebagainya. ${ }^{10}$

Seperti yang dikemukakan oleh Ismail Toyib, bahwa pendidikan PAI memiliki tujuan pokok yaitu membentuk pribadi muslim yang segala dimensi kehidupannya diwarnai oleh nilai-nilai islami, inilah yang disebut dengan akhlaqul karimah. ${ }^{11}$ Dari penjelasan di atas bahwa hakikat tujuan pendidikan Agama Islam adalah membentuk pribadi muslim, maka kurikulum dan pelaksanaan pendidikan Islam sangat menekankan pentingnya penanaman nilai-nilai keagamaan. Adapun istilah keagamaan dalam tulisan ini adalah agama Islam itu sendiri, akan tetapi tidak hanya pada materi semata melainkan pada praktik dan penghayatan nilai-nilainya dalam kehidupan sehari-hari

\footnotetext{
${ }^{9}$ Muhaimin, Nuansa Baru Pendidikan Islam, Mengurai Benang Kusut Dunia Pendidikan, (Jakarta: Raja Grafindo Persada, 2006). Hlm.147.

${ }_{10}$ Zulkarnain, Transpormasi Nilai-Nilai Pendidikan Islam (Yogyakarta:Pustaka Pelajar, 2008). Hlm. 26.

${ }^{11}$ Ismail Toyib, Wacana Baru Pendidikan, Meretas Filsafat Pendidikan Islam (Yogyakarta: Genta Press, 2007). Hlm. 160
} 
sehingga menjadi manusia yang bermartabat tinggi dalam lintas agama, nusa dan bangsa. ${ }^{12}$

\section{METODOLOGI PENELITIAN}

\section{Pendekatan Penelitian dan Kehadiran Peneliti}

Mengacu pada judul yang diangkat oleh peneliti dalam penelitian ini setelah membentuk variabel-variabel dalam judul tersebut, baik variabel devendentnya maupun indevendentnya yang menggambarkan satu usa guru dalam meningkatkan kualitasnya sebagai tenaga pengajar, maka peneliti menggunakan pendekatan kualitatif, karena data-data yang dikumpulkan berupa informasi-informasi atau pesan-pesan, pendapat, konsep, keterangan, tanggapan yang berbentuk uraian dalam mengungkapkan permasalahan yang ada. Sugiyono menyebutkan bahwa penelitian kualitatif adalah penelitian yang berlandaskan pada filsafat postofositifisme, digunakan untuk meneliti pada kondisi obyek yang alamiah, dalam hal ini peneliti sebagai instrumen kunci, pengambilan sampel, teknik pengumpulan data dengan triangulasi (gabungan), analisis data bersifai induktif/deduktif dan hasilnya lebih menekankan pada makna daripada generesasi. ${ }^{13}$ hal tersebut diperkuat oleh Moleong yang menyatakan bahwa metode ini lebih peka dan lebih dapat menyesuaikan diri dengan banyak penajaman pengaruh bersama terhadap pola-pola nilai yang dihadapi. ${ }^{14}$ Adapun alasan menggunakan pendekatan kualitatif adalah peneliti akan lebih kreatif dalam mengumpulkan data dan informasi lapangan karena dapat memanfaatkan nalar dalam memecahkan masalah yang dihadapi serta dapat mengembangkan hal-hal yang dapat mendukung keabsahan data yang didapat dari lokasi penelitian.

\section{A. Lokasi Penelitian dan Sumber Data serta Prosedur Pengumpulan data}

Penelitian dilakukan di SDN 1 Lembah Sari Kecamatan Batu Layar. Terkait dengan sumber data penelitian dengan populasi yang cukup besar, maka dalam penelitian kualitatif tidak ada sampel acak tetapi sampel yang bertujuan (Purposive sampel). Adapun sumber data yang dapat membantu untuk mendapatkan data yaitu pertama berupa orang ( Guru, Murid SDN 1 Lembah Sari, Guru BK, Kepala Sekolah dan wali SDN 1 Lembah

${ }^{12}$ Mappanyompa, Pendidikan Islam Menurut M. Quraish Shihab Dalam Terjemahan Tafsir Al-Misbah Melalui Kajian Hermeneutika, 2016 (Jurnal: Ilmiah Tata Sejuta), Hal, 59-69

\footnotetext{
13 Sugyono, Metode Penelitian Pendidikan pendekatan kualitatif kuantitatif $R \& D$ (Bandung: Alpabeta, 2006), hlm.15

${ }^{14}$ Lekxi Moleong, Metodologi Penelitian Kualiatatif (Bandung: PT Remaja Rosdakarya, 2008), hlm. 9
}

Sari. Ke dua yaitu barang atau benda ( Struktur Organisasi, Gedung Kelas, dan Media Pembelajaran lainnya). Dan yang ketiga adalah situasi dan kondisi yaitu ketika terjadi pembelajaran, lingkungan sekolah dan keadaan geografis sekolah serta keadaan sosial masyarakat. Terkait dengan prosedur pengumpulan data dalam penelitian ini ada beberapa hal yang dilakukan yaitu membuat perencanaan penelitian, survei awal, izin instansi terkait, menentukan sumber data dan pengumpulan data dengan metode wawancara kepada guru mata pelajaran PAI, kepala sekolah, wali kelas, petugas imtaq dan guru diniyah. Adapun metode observasi ini secara langsung terjun pada lokasi penelitian untuk mengamati langsung dan mencatat secara sistematik gejalagejala yang di selidiki. ${ }^{15}$ Adapun yang diselidiki terkait dengan implementasi program IMTAQ nilai-nilai keagamaan yang ditanamkan pada siswa SDN 1 Lembah Sari, dan kendala-kendala guru dalam melaksanakan program tersebut.

Sedangkan yang didokumentasi adalah kegiatan pelaksanaan IMTAQ, jadwal Imtaq dan Diniyah.

\section{B. Analisis Data dan Validitas Data}

Analisi data yang digunakan adalah analisis induktif yakni data yang ada dilapangan kemudian mensintesiskannya dalam beberapa kategori atau mencocokkannya dengan teori yang ada. ${ }^{16}$

Adapun validias data yang digunakan dalam penelitian ini adalah ketekunan pengamatan, triangulasi data yang diperoleh dari guru dengan data yang diperoleh dari hasil observasi. Validasi data juga dilakukan dengan pemeriksaan sejawat melalui diskusi dan telaah bahan refrensi.

\section{TEMUAN DAN HASIL PENELITIAN}

\section{Setting Penelitian}

Secara geografis, SDN 1 Lembah Sari terletak di dusun tibu Ambung desa Lembah Sari Kecamatan Batulayar lombok Barat. Terkait dengan jumlah siswa bahwa pada awalnya terus mengalami peningkatan jumlah siswa, akan tetapi pada tahun belakangan ini mengalami penurunan drastis karena adanya persaingan dengan sekolah yang ada di desa kekait, dan salah satu faktornya juga adalah banyak orang tua yang lebih memilih menyekolahkan anaknya di luar desa, kondisi ini sebanarnya menjadi indikator bahwa programprogram yang ada disekolah tidak dapat menarik simpati warga setempat. ${ }^{17}$

\footnotetext{
${ }^{15}$ Supardi, Metodologi Penelitian (Mataram: Yayasan Cerdas Press, 2006). Hlm. 88

${ }^{16}$ M. Toha Anggoro dkk, Metode Penelitian, (Jakarta: Universitas Terbuka, 2007). Hlm. 618. 2017.

${ }^{17}$ Wawancara, Mukmin, Kepala SDN 1 Lembah Sari. Senin 3 Oktober
} 
Penjelasan kepala sekolah tersebut berbanding lurus dengan apa yang ditemukan pada

\begin{tabular}{|l|l|l|l|l|}
\hline No & Hari & Kegiatan & $\begin{array}{l}\text { Penanggung } \\
\text { Jawab }\end{array}$ & Ket \\
\hline 1 & Jumat & Imtaq & $\begin{array}{l}\text { Kasek dan } \\
\text { Guru }\end{array}$ & Terjadwal \\
\hline 2 & Senin & $\begin{array}{l}\text { Diniyah } \\
\text { Sore }\end{array}$ & $\begin{array}{l}\text { Guru } \\
\text { Agama }\end{array}$ & Terjadwal \\
\hline 3 & Selasa & $\begin{array}{l}\text { Diniyah } \\
\text { Sore }\end{array}$ & $\begin{array}{l}\text { Guru } \\
\text { Agama }\end{array}$ & Terjadwal \\
\hline 4 & Rabu & $\begin{array}{l}\text { Diniyah } \\
\text { Sore }\end{array}$ & $\begin{array}{l}\text { Guru } \\
\text { Agama }\end{array}$ & Terjadwal \\
\hline 5 & Kamis & $\begin{array}{l}\text { Diniyah } \\
\text { Sore }\end{array}$ & $\begin{array}{l}\text { Guru } \\
\text { Agama }\end{array}$ & Terjadwal \\
\hline 6 & Jumat & $\begin{array}{l}\text { Diniyah } \\
\text { Sore }\end{array}$ & $\begin{array}{l}\text { Guru } \\
\text { Agama }\end{array}$ & Terjadwal \\
\hline
\end{tabular}

lokasi penelitian, yaitu program yang ada terkesan seperti rutinitas biasa sehingga tidak memiliki daya tarik. Padahal program IMTAQ yang ada di sekolah tersebut berjalan dengan lancar bahkan ada tambahan waktu yaitu ada kegiatan diniyah yang dilaksanakan sore hari sekitar pukul 15.40sampai selesai.

Terkait dengan jumlah siswa yang mengalami penurunan, berikut data siswa SDN 1 Lembah Sari tahun ajaran 2017/2018 seperti pada tabel berikut:

Tabel. 4.1

Jumlah Siswa SDN 1 Lembah Sari TA.2017/2018

\begin{tabular}{|l|l|l|l|}
\hline No & kelas & $\begin{array}{l}\text { Jumlah } \\
\text { siswa/siswi }\end{array}$ & keterangan \\
\hline 1 & I & 19 & \\
\hline 2 & II & 22 & \\
\hline 3 & III & 23 & \\
\hline 4 & IV & 25 & \\
\hline 5 & V & 21 & \\
\hline 6 & V1 & 20 & \\
\hline Jlm & 6 kelas & 130 & \\
\hline
\end{tabular}

Dari data jumlah siswa di atas, menunjukkan bahwa jumlah siswa/siswi terjadi penurunan, karena masyarakat kurang minat untuk menyekolahkan anaknya karena menganggap program sekolah kurang menaruk simpati warga setempat.

\section{A. Implementasi Program IMTAQ Sebagai Upaya Penguatan Nilai-Nilai Keagamaan Anak di SDN 1 Lembah Sari}

Implementasi program IMTAQ di setiap sekolah merupakan program wajib guna meningkatkan iman dan taqwa para siswa. Maka dalam merealisasikan program IMTAQ para siswa/i melakukannya dengan dua program yaitu program imtaq setiap jumat pagi dan tambahan diniyah sore yang diselenggarakan lima kali setiap pekan yakni dari seni sampai jum'at. Untuk jelasnya kegiatan tersebut seperti pada tabel berikut:

Tabel.4.2

\section{Kegiatan Imtaq dan Diniyah SDN 1 Lembah Sari}

Seperti sekolah lainnya, SDN 1 Lembah Sari melaksanakan kegiatan imtaq dan diniyah seperti dalam jadwal, kegiatan tersebut diisi dengan program membaca al-qur'an berjamaah, setelah itu ada pesan-pesan bijak dari bapak/ibu guru atau yang bertugas pada saat imtaq ${ }^{18}$. Mukmin menjelaskan bahwa program imtaq di SDN 1 Lembah Sari merupakan realisai dari uu sisdiknas yang kemudian diinstruksikan kepada setiap sekolah untuk mengadakan imtaq. ${ }^{19}$ Terkait dengan hal tersebut Khairudin guru PAI menjelaskan untuk meningkatkan pemahaman keagamaan siswa, sekolah memprogramkan imtaq dan diniyah. ${ }^{20}$

Adapun program diniyah bertujuan agar siswa memiliki tambahan ilmu keislaman sebagai akibat terbatasnya waktu belajar agama Islam di dalam kelas. ${ }^{21}$ Dalam bukunya Novan Ardy menyebutkan bahwa tujuan dari integrasi iman dan taqwa dalam visi, misi, tujuan dan strategi sekolah dalam meraih tujuan pendidikan Nasional antara lain:

1. mengembangkan wawasan spiritual yang semakin mendalam dan mengembangkan pemahaman rasional mengenai islam dalam konteks kehidupan moderen.

2. Membekali anak didik dengan berbagai kemampuan pengetahuan dan kebajikan.

3. Mengembangkan kemampuan pada diri anak untuk menghargai dan membenarkan superioritas komparatif kebudayaan dan peradaban islam.

4. Membantu anak yang sedang tumbuh untuk belajar berfikir secara logis dan membimbing proses pemikirannya dengan bijak. ${ }^{22}$

Seperti yang dikemukakan oleh Ismail Toyib, bahwa pendidikan PAI memiliki tujuan pokok yaitu membentuk pribadi muslim yang segala dimensi kehidupannya diwarnai oleh nilai-nilai islami, inilah yang disebut dengan akhlaqul karimah. ${ }^{23}$ Dari penjelasan di atas bahwa hakikat tujuan

\footnotetext{
${ }^{18}$ Observasi program imtaq, 6 Oktober 2017.

${ }^{19}$ Wawancara, Mukmin Kepala Sekolah, 6 Oktober 2017.

${ }^{20}$ Wawancara, Khairudin Guru PAI, 16 Oktober 2017.

21 Wawancara, Ust. Subki, Penanggungjawab program diniyah, 17 oktober

${ }^{22}$ Novan Ardy Wiyani, Pendidikan Karakter Berbasis Iman dan Taqwa, (yogyakarta: Teras. 2002). Hal 71.

${ }^{23}$ Ismail Toyib, Wacana Baru Pendidikan, Meretas Filsafat Pendidikan Islam (Yogyakarta: Genta Press, 2007). Hlm. 160
} 
pendidikan Agama Islam adalah membentuk pribadi muslim, maka kurikulum dan pelaksanaan pendidikan Islam sangat menekankan pentingnya penanaman nilai-nilai keagamaan. Adapun istilah keagamaan dalam tulisan ini adalah agama Islam itu sendiri, akan tetapi tidak hanya pada materi semata melainkan pada praktik dan penghayatan nilai-nilainya dalam kehidupan sehari-hari sehingga menjadi manusia yang bermartabat tinggi dalam lintas agama, nusa dan bangsa.

B. Materi- Materi IMTAQ yang ditanamkan pada siswa dalam rangka Penguatan NilaiNilai Keagamaan Anak di SDN 1 Lembah Sari

Adapun materi-materi imtaq yang ada di SDN 1 Lembah Sari dibagi dua materi yaitu Imtaq rutin setiap jumat dan kegiatan Diniyah. Adapun materi-materi imtaq setiap jum'at yaitu diawali dengan doa keseharian, dilanjutkan dengan membaca surah yasin dan ditutup dengan ceramah yang disampaikan oleh guru yang bertugas pada saat imtaq atau perwakilah dari siswa/i. Sedangkan materi diniyah adalah terkait dengan rukun iman, rukun islam, fiqih,aqidah tersebut dengan rincian pembahasannya. ${ }^{24}$

Pengambangan yang lebih dalam terkait dengan rukun iman dan rukun Islam, ketua panitia ust. Subki memberikan tanggungjawab sepenuhnya terhadap guru-guru diniyah yang mengampu, yang pastinya secara umum sudah disepakati dan sudah disesuaikan dengan jenjang siswa. ${ }^{25}$ Sebagai perbandingan perlu dilakukan pengembangan materi seperti syahadatain, tauhid, risalah, dan lain sebagainya yang harus dikembangkan sehingga tidak terkesan monoton. ${ }^{26}$

\section{Kendala yang dihadapi dalam program IMTAQ di SDN 1 Lembah Sari}

Setiap kegiatan yang dilakukan pastinya ada kendala-kendala yang dihadapi baik kendala internal maupun kendala eksternal. Sepanjang pengamatan yang dilakukan dilapangan, kedua sumber itu menjadi kendala baik dari guru maupun dari siswa. Akan tetapi, kendala yang masih ada didominasi dari arah siswa.

Kendala yang sering dihadapi dalam pelaksanaan IMTAQ banyak sekali dari hal-hal yang sifatnya teknis sampai pada yang sifatnya substantif. Kendala teknis yang dimaksud adalah fasilitas pengeras suara yang tidak mendukung. Tempat pelaksanaan yang kurang refresentatif dan jadwal yang belum baku. Sedangkan kendala substantif yang dimaksud adalah sering terjadi ketidak siapan guru dan siswa dalam

\footnotetext{
${ }^{24}$ Observasi, 17-24 oktober 2017.

${ }^{25}$ Wawancara ust. Subki 20 Oktober 2017.

${ }^{26}$ Khatoon Gazi, Kurikulum Skolah Dasar Iqra (Jakarta: Bina Mitra Press).
}

menyampaikan materi pidato atau kultum setiap hari jumat.

\section{E. KESIMPULAN}

Berdasakan uraian, analisa dan pembahasan di atas tentang implementasi program IMTAQ sebagai upaya peningkatan nilainilai keagamaan anak SDN Lembah Sari dapat disimpulkan sebagai berikut:

1. Realisai kegiatan IMTAQ di SDN 1 lembah Sari dengan dua kegiatan yakni dengan kegiatan jumat rutin dan kegiatan diniyah sore, pelaksanaannya lima hari setiap pekan, adapun materi-materi yang diajarkan adalah materi yang bersentuhan dengan kebutuhan dalam hal praktek keagamaan sehari-hari. Materi yang mendasar bagi siswa adalah rukun iman, rukun Islam dan doa-doa keseharian.

2. Materi tersebut diberikan secara teoritis dan praktis, hal tersebut dimaksudkan agar apa yang telah dipelajari oleh siswa langsung dapat dipraktikkan oleh siswa dalam kehidupan sehari-hari.

3. Secara umum ada dua kendala yang dihadapi dalam implementasi IMTAQ yakni kendala teknis dan kendala substantif lebih pada kurang siapnya guru dan siswa dalam menyampaikan pidato (kultum) setiap kegiatan IMTAQ berlangsung.

\section{F. DAFTAR RUJUKAN}

Hamruni, Strategi dan Model-Model Pembelajaran Aktif Menyenangkan, 2009 (Yogjakarta: UIN Suka Press).

Ismail Toyib, Wacana Baru Pendidikan, Meretas Filsafat Pendidikan Islam, 2007 (Yogyakarta: Genta Press).

Khatoon Gazi, Kurikulum Skolah Dasar Iqra (Jakarta: Bina Mitra Press).

Lekxi Moleong, Metodologi Penelitian Kualiatatif . 2008 (Bandung: PT. Remaja Rosdakarya,).

M. Toha Anggoro dkk, Metode Penelitian, 2007 (Jakarta: Universitas Terbuka).

Muhammad Alim, Pendidikan Agam Islam, Upaya Pembentukan Pemikiran dan kepribadian Muslim 2006 (bandung: Rosdakarya).

Supardi, Metodologi Penelitian, 2006 (Mataram: Yayasan Cerdas Press).

Sugyono, Metode Penelitian Pendidikan pendekatan kualitatif kuantitatif R\&D. 2006 (Bandung: Alpabeta,).

Muhaimin, Arah Baru Pengembangan Pendidikan Islam, 2003 (Bandung: Nuansa Cendekiawan,) 
Mappanyompa, Pendidikan Islam Menurut $M$. Quraish Shihab Dalam Terjemahan Tafsir Al-Misbah Melalui Kajian Hermeneutika, 2016 (Jurnal: Ilmiah Tata Sejuta), Hal, 59-69

Muhaimin, Nuansa Baru Pendidikan Islam, Mengurai Benang Kusut Dunia Pendidikan, 2006 (Jakarta: Raja Grafindo Persada)

Novan Ardy Wiyani, Pendidikan Karakter Berbasis Iman dan Taqwa, 2002 (yogyakarta: Teras).

Tolhan dan Barizi, Membuka Jendela Pendidikan, mengurai akar Tradisi dan Integrasi Keilmuan Pendidikan Islam, 2004 (Jakarta: Grafindo Persada).

Tim Reality, Kamus Terbaru Bahasa Indonesia, 2008 (Surabaya: Reality Publisher).

Zulkarnain, Transpormasi Nilai-Nilai Pendidikan Islam, 2008 (Yogyakarta:Pustaka Pelajar 